Anna Milewska

Szkoła Glówna Gospodarstwa Wiejskiego w Warszawie

\title{
Centra usług wspólnych jako podmiot racjonalizujący koszty w organizacji - skala i zakres dzialania w Polsce
}

\author{
SHARED SERVICES CENTER AS AN ENTITY \\ RATIONALIZING COSTS IN THE ORGANIZATION - \\ SCALE AND SCOPE OF ACTION IN POLAND
}

Celem artykułu było zaprezentowanie specyfiki, zakresu i skali działania Centrów Ustug Wspólnych $w$ Polsce. Sq to podmioty racjonalizujace koszty, tworzone glównie przez międzynarodowe organizacje działajace $w$ sferze biznesu.

$W$ artykule zdefiniowane zostaty determinanty lokalizacji tych jednostek oraz rodzaje ustug świadczone w ramach Centrów. Ponadto wskazano także na zależność dotyczqca rozwoju centrów ustug wspólnych a wzrostem liczy miejsc pracy w innych branżach. Aby osiagnać założony cel Autorka postużyta się m.in. danymi publikowanymi w raportach Zwiazku Liderów Sektora Ustug Biznesowych (ABSL), który jest wiodaca organizacja reprezentujaca nowoczesne ustugi dla biznesu w Polsce. Podmiot ten skupia centra ustug wspólnych, outsourcingu procesów biznesowych, outsourcingu, centra badawczo-rozwojowe (Research\&Development, $R \& D$ ) oraz firmy wspierajace rozwój sektora.

Ponadto $w$ artykule zwrócono także uwage na instrumenty New Public Managment tj. możliwości tworzenia Centrów Ustug Wspólnych w podsektorze samorzqdowym.

Słowa kluczowe: Centrum Usług Wspólnych, koszty, racjonalizacja.

\section{Wstęp}

Prowadzenie działalności gospodarczej, niezależnie od jej specyfiki, rozmiaru czy zakresu geograficznego jest nieuchronnie związane z potrzebą ponoszenia kosztów. Wraz z jej dynamicznym rozwojem niezbędną staje się również optymalizacja procesów, w tym także tych związanych z polityką wydatkową.

Utworzenie takiego podmiotu jak Centrum Usług Wspólnych pozwala na redukcję funkcji powielanych $\mathrm{w}$ oddziałach $\mathrm{i}$ skoncentrowanie ich $\mathrm{w}$ jednym miejscu. W konsekwencji daje to możliwości obniżki kosztów bezpośrednich oraz wzrostu korzyści skali świadczonych usług ${ }^{1}$. Ze względu na możliwe do osiągnięcia efekty coraz więcej firm decyduje się na utworzenie centrum usług wspólnych. Wyniki badań przeprowadzonych przez Deloitte wykazały, że w ciągu dziesięciu lat liczba tworzonych $\mathrm{SSC}^{2}$ podwoiła się $\mathrm{e}^{3}$. Centrum Usług Wspólnych Shared Services Center to centrum

\footnotetext{
${ }^{1}$ S. M. Szukalski, Procesowe i organizacyjne innowacje w Centrach Usług Wspólnych, Acta Universitas Lodziensis, Folia Oeconomia 268, 2012, s. 110

${ }^{2}$ SSC - Shared Services Center
} 
utworzone wewnątrz grupy kapitałowej przedsiębiorstwa, jako oddzielna spółka; zazwyczaj scentralizowana jednostka, ulokowana poza granicami kraju spółki matki, realizująca procesy dla klientów wewnętrznych i zewnętrznych na całym świecie. ${ }^{4}$ Zalety posiadania SSC dla wielkich holdingów są liczne i związane głównie ze standaryzacją i ujednoliceniem obsługi procesów, którymi się zajmują. Jednakże biorąc pod uwagę wartość dodaną, jaką przynoszą lokalnej gospodarce nowe centra usług dla biznesu stały się one także, w ostatnich kilku latach jednym, z głównych celów Polskiej Agencji Informacji i Inwestycji Zagranicznych (aktualnie Polska Agencja Inwestycji i Handlu). Stąd też starania rządów poszczególnych krajów o nowe projekty inwestycyjne i bogata paleta instrumentów wsparcia, jakie oferują inwestorom ${ }^{6}$. Celem działalności centrów jest przede wszystkim redukcja kosztów działalności spółek macierzystych i to właśnie ta kosztowa efektywność sprawia, że liczba takich ośrodków rośnie zarówno w Polsce jak i innych krajach globalnie. ${ }^{7}$

W związku ze zmianami ustawy o samorządzie gminnym wprowadzonymi z dniem 1 tycznia 2016, także gmina jako jednostka samorządu terytorialnego może zapewnić wspólną obsługę dotyczącą spraw organizacyjnych, administracyjnych czy finansowych ${ }^{8}$. Obsługa ta może być realizowana na rzecz jednostek organizacyjnych gminy zaliczanych do sektora finansów publicznych, gminnych instytucji kultury czy osób prawnych utworzonych na podstawie odrębnych przepisów w celu wykonywania zadań publicznych. Zgodnie z ideą New Public Management zakłada się bowiem stopniowe eliminowanie biurokratycznego modelu administracji publicznej, w tym także samorządowej. Miejsce dotychczasowych rozwiązań, skupionych na realizacji wydatków zastąpić ma menadżerski model zarządzania środkami publicznymi. Koncepcja ta, polega także na wieloletnim zdefiniowaniu celów, beneficjentów a także określenia efektów podjętych przedsięwzięć. Ze względu na rosnące potrzeby społeczeństwa związane $\mathrm{z}$ jego rozwojem $\mathrm{z}$ jednej strony a ograniczonością dóbr $\mathrm{i}$ zasobów z drugiej, wdrożenie takich rozwiązań zdaje się być nieuniknione. Ze względu na specyfikę funkcjonowania samorządów, począwszy od ich istoty po realizację usług publicznych zabezpieczających potrzeby lokalnej wspólnoty, powołanie Centrum Usług Wspólnych na tej płaszczyźnie będzie charakteryzowało się odmiennością. Nie będzie zatem w tym wymiarze, co do zasady, wyłączną przesłanką ograniczenie czy racjonalizacja „kosztów”, tak jak to ma miejsce w podmiotach posługujących się

\footnotetext{
${ }^{3}$ Richter, P. C. i Brühl, R. (2017). Shared service center research: A review of the past, present, and future. European Management Journal, 35(1), 26-38. https://doi.org/10.1016/j.emj.2016.08.004 za A. Hauke-Lopes, Proces tworzenia centrum usług wspólnych ba przykładzie grupy Euroflorist, Studia Oeconomia Posnaniensia 2018, vol. 6, no 4., s. 82

${ }^{4}$ A. Wodecka - Hyjek, Outsourcing i co-sourcing jako formy współpracy dostawcy i odbiorcy usług, Zeszyty Naukowe Akademii Ekonimicznej, nr 670, Kraków 2005, s. 5.

5 M. Błaszkowska, Shared Services Center. Korzyści nie tylko dla dużych organizacji?, Controlling i Rachunkowość Zarządcza 4/2018

https://www.controllingirachunkowosc.pl/autorzy/monika-blaszkowska dostęp 19.10.2018

${ }^{6}$ M. Kozak, Rozwój sektora nowoczesnych usług dla biznesu w Polsce, Zeszyty Naukowe Politechniki Częstochowskiej, Zarządzanie Nr 28 t. 1 (2017) s. 60

${ }^{7}$ Przegląd 300 międzynarodowych centrów usług: definicje, segmentacja, zatrudnienie, planu i prognozy, Biuro Badawczo-Analityczne DiS, Warszawa 2008, s. 3. www.paiz.gov.pl/files/?id_plik=10380 dostęp 10.11.2018

${ }^{8}$ Ustawa z dnia 8 marca 1990 r. o samorządzie gminnym, Dz. U. 1990, Nr 16 poz. 95 tj. Dz. U. z 2018 r. poz. $994,1000,1349,1432$
} 
kategorią „zysków” a nacisk na sprawności i efektywność działania administracji publicznej.

\section{Centrum Usług Wspólnych - istota i zakres}

Według danych zamieszczonych w raporcie Związku Liderów Sektora Usług Biznesowych (ABSL), największy przyrost centrów usług z kapitałem zagranicznym ${ }^{9} \mathrm{w}$ Polsce datuje się na lata 2010 - 2012, gdzie liczba istniejących podmiotów wzrosła z 90 do ponad 300 ośrodków. W Polsce funkcjonuje około 1000 centrów o kapitale zagranicznym, które zatrudniają łącznie ponad 212 tysięcy osób w dziesięciu największych ośrodkach biznesowych: Warszawie, Krakowie, Wrocławiu, Łodzi, Trójmieście, Poznaniu, Rzeszowie oraz w ramach aglomeracji katowickiej ${ }^{10}$ a liczba zatrudnień w tych podmiotach sukcesywnie wzrasta. Pojedyńcze ośrodki zlokalizowane są także w mniejszych miastach, zapewniając nowe miejsca pracy ich mieszkańcom, np. w Szczecinie, Bydgoszczy, Lublinie, Opolu, Częstochowie, Radomiu, Olsztynie, Bielsko - Białej, Toruniu, Pile czy w Zielonej Górze. Największy przyrost zatrudnienia odnotowano przede wszystkim w Lublinie oraz Rzeszowie, gdzie jego poziom w roku 2016 był wyższy o blisko 100\% w stosunku do 3 poprzedzających lat. Biorąc pod uwagę dotychczasowy rozwój branży można szacować, że w 2020 roku centra usług w Polsce będą zatrudniać co najmniej 300 tys. osób ${ }^{11}$.

Wraz ze wzrostem liczby centrów, tendencję wzrostową wykazuje także liczba miejsc pracy. Według danych z autorskiego raportu ABSL, 83\% zatrudnień w sektorze zawdzięcza się właśnie kapitałowi zagranicznemu. W latach 2013 - 2016, zagraniczne firmy wygenerowały bowiem 77 tysięcy nowych miejsc pracy, co średniorocznie stanowi $21 \%$ wzrost $^{12}$ Warto, w tym miejscu także nadmienić, iż podmioty te obok utworzenia oferują także dobrze płatne stanowiska pracy dla absolwentów uczelni. Pożądani są absolwenci zarówno kierunków związanych z informatyką, jak również finansów i rachunkowości czy ekonomii.

Analiza polskiej mapy w ramach sektora usług wspólnych wskazuje, iż największą posiadaną przewagą konkurencyjną jest geograficzna dostępność ośrodków, które stanowić mogą miejsce lokalizacji dla kolejnych inwestycji. W badaniu ankietowym przeprowadzonym przez pracowników ABSL na próbie 215 centrów usług wspólnych w Polsce, ich liderzy zwracali uwagę przede wszystkim na dogodną lokalizację Polski na tle innych krajów europejskich, Natomiast w kontekście samych ośrodków miejskich na dostępność nowoczesnej powierzchni biurowej oraz bardzo dobrze rozwiniętą komunikację, zarówno w rozumieniu jakości komunikacji miejskiej, jak i dostępności kolejowej, portów lotniczych czy wodnych. Na rysunku 1 przedstawione zostały udziały wybranych lokalizacji w ogólnym zatrudnieniu w ramach sektora usług wspólnych w Polsce za rok 2016.

\footnotetext{
${ }^{9}$ Przez centra usług z kapitałem zagranicznym należy rozumieć ogół centrów (w tym: BPO, SSC, IT, R\&D)

${ }^{10}$ J. Górecki, K. Gurszyńska, Ł. Karpiesiuk, M. Polkowski, Sektor Nowoczesnych Usług Biznesowych w Polsce 2016, Raport ABSL, Warszawa 2016, s. 9 i n. https://absl.pl/wpcontent/uploads/2016/10/Raport_ABSL_2016_PL.pdf dostęp 09.10.2018

${ }^{11}$ Ibidem

12 Ibidem, s. 21.
} 


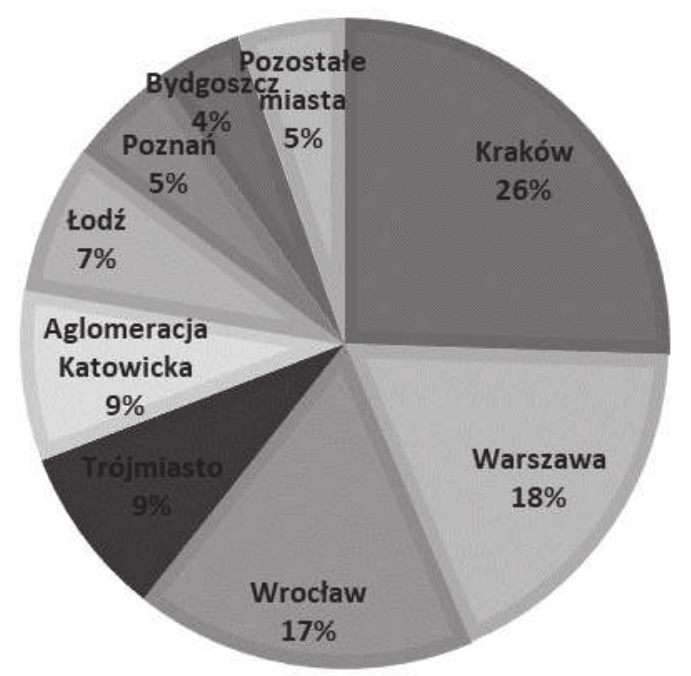

Rysunek 1. Udział lokalizacji w ogólnym zatrudnieniu w ramach sektora usług wspólnych w Polsce e za rok 2016.

Źródło: opracowanie własne na podstawie J. Górecki, K. Gurszyńska, Ł. Karpiesiuk, M. Polkowski, Sektor... op. cit., s. 14.

Znaczącą rolę dla obecnych oraz potencjalnych inwestorów odgrywają także współpraca z lokalnymi władzami, jak również wizerunek samego ośrodka (np. Warszawa - stolica Polski; Wrocław - centrum kulturowe, etc.). ${ }^{13} \mathrm{Z}$ tego względu, część nowych centrów, które powstały po roku 2015 nie stanowią nowych inwestycji per se są to reinwestycje tych firm, które $\mathrm{z}$ powodzeniem prowadzą już swoją działalność w innych miastach Polski. Przykładem takich działań jest szwajcarski bank UBS (Union Bank of Switzerland). W 2007 roku, pierwsze biuro banku w Polsce rozpoczęło pracę w Zabierzowie (w okolicach Krakowa), zatrudniając łącznie ponad 800 osób. Obecnie, UBS rozwija kolejną lokalizację - tym razem we Wrocławiu, która stanowić ma integralną część całości biznesu banku. Szacowana liczba zatrudnień dla biura wrocławskiego to 600 nowych pracowników. ${ }^{14}$ Firmy z sektora finansów to nie jedyny przykład rozwoju działalności o kolejne lokalizacje. Przykładem jest również firma Diebold - Nixdorf, która poza biurem warszawskim rozwija kolejne centrum w Szczecinie, bądź Luxoft w Krakowie i Trójmieście. Zarówno wzrost zatrudnienia jak i ekspansja o nowe oddziały w Polsce są świadectwem dużego sukcesu centrów usług wspólnych na polskim rynku pracy i mogą świadczyć o powstawaniu nowego trendu, jeśli taki wzrost zostanie utrzymany.

\footnotetext{
${ }^{13}$ J. Górecki (red.), Sektor Nowoczesnych Usług Biznesowych w Polsce 2017, Raport ABSL, Warszawa 2017, s. 18.

14 http://wroclaw.wyborcza.pl/wroclaw/1,35771,19539494,szwajcarski-bank-ubs-zatrudnia-po-cichu-otwieranowe-biuro.html?disableRedirects=true dostęp 10.11.2017.
} 


\section{Rodzaje usług świadczonych w ramach centrów}

Centra usług funkcjonujące w Polsce charakteryzują się znaczną różnorodnością. Wyróżnikiem takich podmiotów jest ścisła, wąska specjalizacja, jednak wiele z nich prowadzi swoją działalność w zakresie kilku różnych procesów biznesowych jednocześnie. Liderami są centra świadczące usługi z obszaru:

- IT (odpowiedzialne za utrzymywanie istniejących systemów oraz tworzenie nowych rozwiązań informatycznych),

- finansów i księgowości (prowadzenie rachunkowości podzielonej na wąskie specjalności, jak zobowiązania, należności, księga główna, podatki, część analityczna i raportowanie), a także

- obsługi klienta (zbieranie zgłoszeń, rozwiązywanie problemów, odpowiadanie na potrzeby klientów w trybie 24/7).

Łącznie, wymienione powyżej kategorie generują ponad $75 \%$ zatrudnienia $\mathrm{w}$ sektorze (rysunek 2).

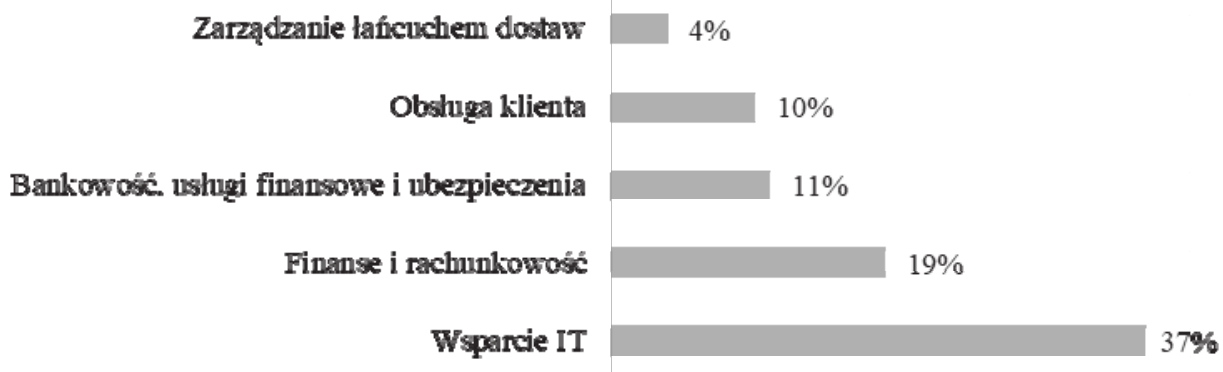

Rysunek 2. Obsługiwane kategorie biznesów w ramach centrów usług w Polsce za rok 2016 Źródło: Opracowanie własne na podstawie J. Górecki, K. Gurszyńska, Ł. Karpiesiuk, M. Polkowski, Sektor... op. cit., s. 28.

Rodzaje procesów obsługiwanych w ramach centrów w dużej mierze uzależnione są od potrzeb spółki macierzystej oraz kraju, w jakim jest ona zlokalizowana. Polscy specjaliści najczęściej wspierają firmy o kapitale lokalnym, amerykańskim, niemieckim, francuskim, brytyjskim, nordyckim, a także azjatyckim. Wynika to nie tylko z uwarunkowań geograficznych i komunikacyjnych, ale przede wszystkim z dostępności wysoko wykwalifikowanej kadry na polskim rynku pracy. Jednym z głównych atutów polskich specjalistów jest dobra znajomość języków obcych pożądanych przez pracodawców. Pod tym względem polscy kandydaci na pracowników prezentują wyższe umiejętności niż inni. Co trzeci Polak deklaruje znajomość przynajmniej jednego języka obcego, zaś pozostałych zakwalifikować można jako poliglotów, posługujących się minimum dwoma językami obcymi. ${ }^{15} \mathrm{~W}$ badaniu Związku Liderów Sektora Usług Biznesowych na temat najbardziej pożądanych biznesowo języków w roku 2017, wzięli udział przedstawiciele 180 centrów w Polsce. Poza najbardziej popularnym językiem

${ }^{15}$ U. Krassowska (red.), Znajomość języków obcych, Raport TNS Polska, Warszawa 2015, s. 2-3. 
angielskim, którego znajomość staję się z roku na rok coraz większym standardem na rynku pracy, badanie wskazało na kilka innych języków obcych o kluczowym znaczeniu dla pracodawców. Należą do nich głównie: niemiecki, francuski, języki nordyckie, niderlandzki i portugalski ${ }^{16}$.

Kolejną ważną kwestią specjalizacją/usługą świadczoną przez centra usług są programy badawczo - rozwojowe R\&D (Research \& Development). Ich zainicjowanie i prowadzenie w Polsce, stanowi dowód wysokich kompetencji polskich specjalistów, co z roku na rok zwiększa liczbę takich inicjatyw dostępnych na polskim rynku pracy. Podstawowym celem takich programów jest utrzymywanie przewagi konkurencyjnej zarówno poprzez powiększanie zasobów wiedzy jak i technologii. Zgodnie z danymi zamieszczonymi w Przegladzie..., wśród centrów istniejących na naszym rynku, około $40 \%$ prowadzi taką działalność. ${ }^{17}$ Zakres programów skupia się głównie wokół zagadnień IT, motoryzacji czy elektroniki, np. w takich firmach jak Samsung, ABB, Alcatel - Lucent bądź Delphi.

Poza szkoleniami wdrożeniowymi oraz treningami umiejętności miękkich (jak komunikacja, inteligencja emocjonalna, zarządzanie czasem, umiejętności negocjacyjne, liderskie, coaching, etc.) organizacje kłada nacisk na szkolenia tzw. kompetencji „twardych” (rysunek 3).

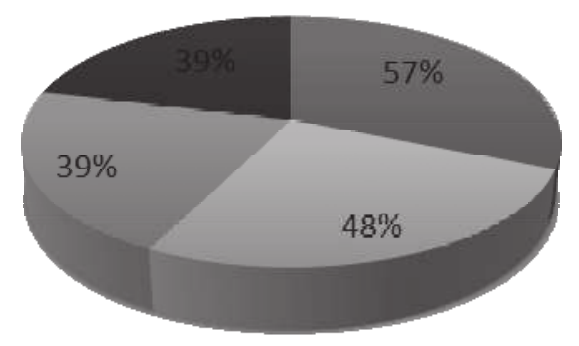

$$
\begin{aligned}
& \text {-Zarządzanie projektami (PMP. Sacrum. Agile) } \\
& \text {-Technologie komputerowe (ITL) } \\
& \text {-Analiza procesów biznesowych (Lean. Six Sigma) } \\
& \text {-Finansowe (ACCA. CIMA. CFA) }
\end{aligned}
$$

Rysunek 3. Szkolenia oferowane pracownikom centrów usług wspólnych w Polsce za rok 2016 Źródło: Opracowanie własne na podstawie J. Górecki, K. Gurszyńska, Ł. Karpiesiuk, M. Polkowski, Sektor... op. cit., s. 37.

Należy w tym miejscu także dodać, iż część pracodawców rozwija ponadto nie tylko własne portfolio biznesowe, ale wspiera także rozwój swoich pracowników, czyniąc ich profile kompetencyjne jeszcze bardziej unikalnymi i wyspecjalizowanymi na polskim rynku pracy.

\footnotetext{
${ }^{16}$ J. Górecki (red.), Sektor... op. cit., s. 18.

${ }^{17}$ Przegląd... op. .cit., s. 10.
} 


\section{Rozwoju centrów usług a wzrost miejsc pracy w innych branżach}

Rosnąca konkurencja o talenty między centrami generuje także nowe miejsca pracy w ramach tych organizacji, które wspierają działania ośrodków na co dzień, np. agencji rekrutacyjnych. Zgodnie z danymi Krajowego Rejestru Agencji Zatrudnienia na dzień 1 stycznia 2016 roku, liczba zarejestrowanych agencji wynosiła ponad 6000 tysięcy. ${ }^{18}$ Według danych portalu kariera.pl, w połowie sierpnia 2017 roku, liczba zarejestrowanych agencji wzrosła już do 8400 tysięcy. ${ }^{19}$ Coraz więcej organizacji, a szczególnie centrów usług wspólnych, korzysta ze wsparcia rekruterów, przeprowadzających zewnętrznie i samodzielnie cały proces rekrutacji. Zgodnie z definicją Mc Kenna, rekrutacja przy wsparciu dostawcy zewnętrznego to proces, który polega na zidentyfikowaniu a następnie wzbudzeniu zainteresowania określonej grupy docelowej pewnymi rolami/stanowiskami w ramach organizacji klientów. ${ }^{20}$

Cechą charakterystyczną rekrutacji dla takich podmiotów, jak centra usług wspólnych, jest ich masowość. Oznacza to, że w tym samym czasie, pracodawca poszukuje kilkunastu - kilkudziesięciu nowych pracowników o zbliżonych kwalifikacjach, często na podobne bądź takie same stanowiska, np. tworząc nowy 10 osobowy zespół specjalistów odpowiadających za konkretny obszar. Bardzo często organizacje, szczególnie takie, które dopiero tworzą swoje struktury na rynku, nie są w stanie samodzielnie zaadresować takich potrzeb, Wówczas zlecają projekty zewnętrznym agencjom rekrutacyjnym a wykwalifikowani w danej dziedzinie konsultanci, w imieniu firmy docierają do najlepszych specjalistów na rynku, prowadzą cały proces i udzielają klientowi porad, np. w zakresie mediany wynagrodzeń.

Poza umową formalną, agencje te podpisują również tzw. zobowiązanie etyczne co oznacza, iż nie będą m.in. angażować pracowników firmy klienta $\mathrm{w}$ żadne procesy rekrutacyjne prowadzone ze swojego ramienia, zaś, jeśli w przeciagu 6 miesięcy zatrudniony kandydat zrezygnuje z podjętej pracy, zobowiązują się do darmowego znalezienia nowej osoby na to miejsce, np. w przeciagu 1 miesiąca. ${ }^{21}$ Dlatego też, rosnące zatrudnienie w obszarze SSC wpływa na wzrost zatrudnienia w sektorze agencji rekrutacyjnych - rynek dostosowuje się bowiem i odpowiada w ten sposób na własne zapotrzebowanie.

Pozytywny wpływ wzrostu liczby m.in. centrów usług wspólnych odczuwalny jest także na rynku nieruchomości. Deweloperzy, chcąc nadążać za potrzebami rynkowymi, inwestują w tworzenie nowych powierzchni biurowych, kreując w ten sposób kolejne miejsca pracy. Zgodnie z danymi ABSL za rok 2016, w samej Warszawie sektor usług dla biznesu wygenerował łącznie około $60 \%$ całkowitego wolumenu najmu. Powierzchnia biurowa w budowie wyniosła natomiast $1500000 \mathrm{~m}^{2}$ za rok $2016 \mathrm{w}$ całym kraju ${ }^{22}$.

Centra przewidują także specjalne udogodnienia dla osób niepełnosprawnych, $\mathrm{m}$. in. należą do nich specjalne miejsca parkingowe, wyposażenie budynków umożliwiające swobodne przemieszczanie się po biurze, a także specjalnie przygotowane miejsca pracy

\footnotetext{
${ }^{18}$ www.stor.praca.gov.pl dostęp 10.11.2017

${ }^{19} \mathrm{https}$ //www.kariera.pl/artykuly/polski-rynek-hr-wart-juz-7-mld-zlotych/ dostęp 11.11.2017

${ }^{20}$ E. Mc Kenna, N. Beech, Zarządzanie zasobami ludzkimi, Wydawnictwo PWE, Warszawa 1998, s. 83.

${ }^{21}$ J. Woźniak, Rekrutacja. Teoria i Praktyka, Wydawnictwo PWN, Warszawa 2013, s. 121.

22 J. Górecki (red.), Sektor... op. cit., s. 40.
} 
i toalety. Dodatkową zachętą pozostaje również elastyczny czas pracy, dodatkowe dni wolne bądź możliwość pracy $\mathrm{z}$ domu, dodatkowe przerwy w ciagu dnia oraz bieżące wsparcie ze strony pozostałych pracowników. ${ }^{23}$

Sektor usług biznesowych bardzo często nawiązuje współpracę z uczelniami wyższymi, przede wszystkim, w celu pozyskiwania przyszłych pracowników wśród studentów i absolwentów. Przedstawiciele biznesu oraz departamentów HR goszczą na uczelniach podczas konferencji, Dni Kariery, Dni Otwartych, przygotowując bezpłatne treningi, sesje, szkolenia czy kursy dla studentów i absolwentów, a w niektórych przypadkach, całe programy stażowe oraz projekty badawcze w ramach swoich organizacji. Dodatkowo, niektóre firmy, jak krakowskie Capgemini prowadzą programy ambasadorskie z możliwością odbycia płatnych praktyk. ${ }^{24} \mathrm{~W}$ efekcie, pracodawcy sami kreują dojrzały oraz $\mathrm{w}$ pełni rozwinięty rynek pracy, który oferuje dostęp do specyficznych, a często niszowych kompetencji, co wykorzystuję kolejne nowopowstające centra usług wspólnych w Polsce.

\section{Podsumowanie}

Powołanie i funkcjonowanie Centów Usług Wspólnych w znacznej mierze do końca 2015 r. dotyczyło organizacji międzynarodowych w sektorze prywatnym. Zakres i skala ich działań miały charakter dynamiczny. Na tle rozwiązań prawnych przyjętych przez ustawodawcę możliwość utworzenia takiego podmiotu od 2016 r. otrzymały także jednostki samorządu terytorialnego. Jednakże formy te charakteryzują się odmiennością.

Na tle przeprowadzonych analiz, Centra Usług Wspólnych tworzone przez sektor biznesowy można wysnuć wniosek, iż skuteczne zarządzanie i optymalizacja kosztów dla organizacji przyczynia się m.in. do wzrostu liczby miejsc pracy. Dotyczy to szczególnie tych obszarów, które są konkurencyjne wobec innych. Ich przewaga dotyczy głównie aspektów lokalizacyjnych, dostępności wykwalifikowanej i mobilnej kadry a także odpowiedzialnej współpracy rekrutacyjnej. Sektor publiczny w Polsce, ze względu na specyfikę swojego funkcjonowania $\mathrm{i}$ przesłanki związane $\mathrm{z}$ realizacją potrzeb społecznych (wiele $\mathrm{z}$ nich nie generuje żadnych dochodów) poszukuje optymalnego modelu zarządzania wydatkami. Przez wzgląd na to, iż w budżetach samorządowych nie są notowane kategorie: straty i zysku, a relacja dochodów i wydatków, Centra Usług Wspólnych przyczynić się mają do ich sprawnego funkcjonowania.

\section{Bibliografia}

Błaszkowska M., Shared Services Center. Korzyści nie tylko dla dużych organizacji?, Controlling i Rachunkowość Zarządeza 4/2018 https://www.controllingirachunkowosc.pl/autorzy/monikablaszkowska dostęp 19.10.2018

Górecki J., Gurszyńska, K., Karpiesiuk Ł., Polkowski M., Sektor Nowoczesnych Usług Biznesowych w Polsce 2016, Raport ABSL, Warszawa 2016, s. 9 i n. https://absl.pl/wpcontent/uploads/2016/10/Raport_ABSL_2016_PL.pdf dostęp 09.10.2018

Górecki J. (red.), Sektor Nowoczesnych Usług Biznesowych w Polsce 2017, Raport ABSL, Warszawa 2017

\footnotetext{
${ }^{23}$ J. Górecki, K. Gurszyńska, Ł. Karpiesiuk, M. Polkowski, Sektor... op. cit., s. 38.

${ }^{24}$ Ibidem, s. 42
} 
Hauke-Lopes A., Proces tworzenia centrum usług wspólnych na przykładzie grupy Euroflorist, Studia Oeconomia Posnaniensia 2018, vol. 6, no 4.

Mc Kenna E.,. Beech N, Zarządzanie zasobami ludzkimi, Wydawnictwo PWE, Warszawa 1998, Kozak M., Rozwój sektora nowoczesnych usług dla biznesu w Polsce, Zeszyty Naukowe Politechniki Częstochowskiej, Zarządzanie Nr 28 t. 1 (2017)

Krassowska U., (red.), Znajomość języków obcych, Raport TNS Polska, Warszawa 2015

Przegląd 300 międzynarodowych centrów usług: definicje, segmentacja, zatrudnienie, planu i prognozy, Biuro Badawczo-Analityczne DiS, Warszawa 2008, www.paiz.gov.pl/files/?id_plik=10380 dostęp 10.11.2018

Richter P. C., i Brühl, R., Shared service center research: A review of the past, present, and future. European Management Journal, 35(1) (2017)., https://doi.org/10.1016/j.emj.2016.08.004

Szukalski S. M., Procesowe i organizacyjne innowacje w Centrach Usług Wspólnych, Acta Universitas Lodziensis, Folia Oeconomia 268, 2012

Ustawa z dnia 25 czerwca 2015 r. o zmianie ustawy o samorządzie gminnym oraz niektórych innych ustaw, Dz.U. z 2015 r., poz. 1045

Ustawa z dnia 8 marca 1990 r. o samorządzie gminnym, Dz. U. 1990, Nr 16 poz. 95 tj. Dz. U. z 2018 r. poz. $994,1000,1349,1432$

Wodecka - Hyjek A., Outsourcing i co-sourcing jako formy współpracy dostawcy i odbiorcy usług, Zeszyty Naukowe Akademii Ekonomicznej, nr 670, Kraków 2005

Woźniak J., Rekrutacja. Teoria i Praktyka, Wydawnictwo PWN, Warszawa 2013.

Pozostałe źródła:

www.stor.praca.gov.pl dostęp 10.11.2017

http://wroclaw.wyborcza.pl/wroclaw/1,35771,19539494,szwajcarski-bank-ubs-zatrudnia-po-cichuotwiera-nowe-biuro.html?disableRedirects=true dostęp 10.11.2017.

https://www.kariera.pl/artykuly/polski-rynek-hr-wart-juz-7-mld-zlotych/ dostęp 11.11.2017

\section{Summary}

The aim of the article was to present the specificity, scope and scale of operation of Shared Service Centers in Poland. It is a cost-rationalizing entity, created mainly by international organizations operating in the sphere of business. The article defines the main determinants of the location of these units and the types of services provided as part of the Centers. In addition, there was also indicated a dependence on the development of shared service centers and the increase in the number of jobs in other industries.

Key words: Shared Services Center, costs, rationalization.

Informacje o autorze:

Dr inż. Anna Milewska

Katedra Finansów

Wydział Nauk Ekonomicznych

e-mail: anna_milewska1@sggw.pl

ORCID: 0000-0003-4776-6049 